\title{
Service Brand Identity Characteristics of Software and IT Companies in Cluj-Napoca
}

\author{
Gyöngyvér Erika TŐKÉS \\ Sapientia Hungarian University of Transylvania \\ Cluj-Napoca, Romania \\ e-mail: gyongyvert@ms.sapientia.ro
}

\begin{abstract}
The development of strong service brand confers market advantage under conditions of strong economic competition (Nádasi, 2016). In creating a strong service brand, the first steps include the elaboration of the service brand identity. The goal of this study consisted in applying the socio-scientific-based brand identity model of Burmann et al. (2017) in the analysis of the service brand identities of three Cluj-Napoca-based software and IT companies. The results of the analysis have shed light on the points of parity of the service brand identities of software and IT companies and highlighted the brand identity elements that enable differentiation (pointsof-difference). The common points of the service brand identity of the Cluj-Napoca-based software and IT companies consisted in the emphasis on technical competences as well as customer and relationship orientation. Their differentiation was possible along their values and personality, which represent the symbolic benefits of service brand identity. Their symbolic differentiation also resulted in the differentiation of their offers.
\end{abstract}

Keywords: service brand, brand identity, socio-scientific brand identity model, software and IT companies in Cluj-Napoca, points of parity and differentiation

\section{Introduction}

In the context of strong economic competition, the success of companies depends not only on the quality of their products and services. The uniqueness of their company identity becomes increasingly important, ensuring both the favourable positioning of the company and its clear separation from the competitors while also positively influencing the development of long-term cooperation relationships with the target groups.

The emphasizing of the company's uniqueness and of the originality of its products and services as well as the creation of the differentiation from its 
competitors falls within the scope of company identity management, one of the strategic areas of which is brand management (Nádasi, 2016: 120).

The brand is a concept that can be connected to the products, services, and the employment of the company or to the company as a whole (Kapferer, 2008: 42). In the process of brand communication, the target audience of the brand encounters the brand representation and forms its own perception of the brand, thus creating the image of the brand. The brand image influences the brand's strength and value, i.e. the brand's influence on purchasing decisions and its financial value (Kapferer, 2008: 43; Chernev, 2017: 162).

The strategic brand analysis and the determination of brand identity are some of the preliminary steps in the process of brand management, which later influence the process of brand planning and implementation (Aaker-Joachimsthaler, 2009: 13). The elaboration of an inspiring brand identity forms the basis for the creation of a strong brand (Aaker-Joachimsthaler, 2009: 292).

The aim of this study is to present the construction of brand identity and to offer an analysis of the service brand identity of companies from the software and IT sector in Cluj-Napoca, based on case studies involving three software and IT companies of this city.

\section{Definition and Structure of Brand Identity}

There are two possibilities for the management when creating the brand: the application of the market-oriented outside-in approach and the identity-based inside-out strategy (Urde-Baumgarth-Merrilees, 2011: 4; Burmann et al., 2017: 26). In the first case, the goal of the brand management activities is to influence the brand image so that it may catch up with the needs of the external target groups (especially of the customers and clients). In the second approach, the emphasis is on the internal anchorage of the brand identity (mission, vision, values). The highlighting of the brand identity is associated with the resource-based approach, in which the brand developers rely on the resources and competences of the company, subsequently shaping the brand-related client expectations through offering these to them (Alsem-Kostelijk, 2008: 911).

Many researchers use the concepts of company identity, company reputation, and company brand interchangeably (Balmer-Gray, 2003: 974). It is, however, worth highlighting that, while all companies have their company identity, it is only those companies who consciously create it who have a brand of any kind (Balmer-Gray, 2003: 980). Brand creation is needed especially in competitive market environments. The strong brands all have some characteristics shared by similar brands (points-of-parity, POP) but also some characteristics that make them unique and outstanding (points-of-difference, POD). Company reputation is 
rather the mirror image of company and brand identity, reflecting the widespread general opinion about the organization. The development of company reputation is significantly impacted by the effectiveness of company identity management, including brand management (Schultz-Hatch-Adams, 2012).

"Brand identity is a set of brand associations that the brand strategist aspires to create or maintain" (Aaker-Joachimsthaler, 2009: 43). Brand identity is a multi-dimensional construct, whose elements form a unit (Kapferer, 2008: 187). Brand identity requires clarity in order to ensure that those involved with the brand all interpret the brand's soul in a similar manner (Aaker-Joachimsthaler, 2009: 40; Kapferer, 2008: 189; Esch, 2008: 62). In the case of a strong brand, the elements of brand identity form a coherent unit and are in accordance with the brand promise. The majority of the authors studying brand identity agree that the external brand perception is associated with the characteristics of brand identity (Burmann-Jost-Benz-Riley, 2009: 391).

Several authors have developed conceptual models for the definition of brand identity and their relationship, the most frequently cited among them being Aaker (2002), Kapferer (2008), and Aaker and Joachimsthaler (2009). These authors use the inside-out orientation of brand identity construction, and their models concern the development of product brands. Also worthy of mention among brand identity models is the corporate brand identity prism of Urde (2013) and the brand identity interpretation of Chernatony (2014). The models mentioned here are conceptual in nature and hardly have been empirically tested (ColemanChernatony-Christodoulides, 2011: 1064). The validity of said models primarily covers the field of B2C, and so they are less applicable in the B2B area (ColemanChernatony-Christodoulides, 2011: 1064).

For the purposes of the present study, the integrated brand identity model of Burmann et al. (2017) deserves special emphasis since it represents the theoretical background for the brand identity analysis of software and IT companies in Cluj-Napoca. The integrated brand identity model of Burmann et al. is based on a social science approach and builds on the tradition and results of personal identity research. Although distancing themselves from the marketing approach, the authors arrive at a brand identity model very similar to the brand identity models based on the marketing perspective. At the same time, the integrated brand identity model of Burmann et al. is of a general nature and can be applied in the empirical research of any brand identity type, regardless of the brand subject. 


\section{Socio-Scientific Model of Brand Identity (Burmann et al., 2017)}

Burmann et al. (2017) have applied the findings of socio-scientific identity research to determine the construction of brand identity. They compared the brand identity to the human identity and the brand image to the social perception of the individual. Burmann et al. (2017: 42) compare the characteristics of weak and strong human identity, subsequently deriving the most important elements of the brand identity construction from the characteristics, resulting in a strong human identity.

According to Burmann et al. (2017: 43), a person with a strong personal identity has a coherent identity in which partial role identities are integrated into a harmonious unity. Such a person may be characterized by some clearly accentuated characteristic properties, while a person with a weak identity changes their identity according to the different situations, and none of their characteristics is too strong. A person with a strong identity assumes the risks associated with change and is thus able to adapt to the changing circumstances, while a person with a weak identity sticks to the existing status quo. Someone with a strong personal identity is able to use the changing circumstances for their own personal development and is thus open to innovative behaviour and experimentation.

The differences between persons with strong and weak identities also manifest in the interaction of the self-perception ant the social perception. People with a strong personal identity do not fully adapt themselves to external expectations but maintain the essential elements of their identity in spite of the role expectations they are confronted with. This requires developed self-confidence, one's own personal values and vision of the future. A person with a strong identity relates to their past experiences consciously, learns and draws strength from them to implement their plans, while persons with a weak identity do not become aware of their abilities and also do not use their past experiences.

According to Burmann et al. (2017: 43), strong personal identity and strong brand identity are manifested in the same manner. Hence, they included into the construction of brand identity the elements that result in strong brand identity.

On the basis of socio-scientific identity research, Burmann et al. (2017: 44) distinguish six constitutive elements which allow a comprehensive description of brand identity: offer, mission/vision, personality, values, competences, and origin.

The offer of brand identity is related to the advantages offered by the brand. The offers are directed both at the external and internal target group. They may have a financial, functional, or symbolic (emotional, social, self-expressive) character. Brand offers are partially similar to the offers of the competing brands of the industry, but they also have to contain individual components which clearly distinguish them. Brand offers are based on the brand competencies (Burmann at el., 2017: 55). 
Table 1. Characteristics of weak and strong identities in people and brands

\begin{tabular}{lll}
\hline \multicolumn{1}{c}{ Characteristics of: } & \multicolumn{1}{c}{$\begin{array}{l}\text { Transfer to brand } \\
\text { identities }\end{array}$} \\
\hline $\begin{array}{l}\text { Many presumed “specific” } \\
\text { identity characteristics }\end{array}$ & $\begin{array}{l}\text { Only a few distinguished } \\
\text { identity characteristics }\end{array}$ & $\begin{array}{l}\text { Brand promise and } \\
\text { brand offer }\end{array}$ \\
\hline $\begin{array}{l}\text { Risk aversion, anxious } \\
\text { maintenance of the status quo }\end{array}$ & $\begin{array}{l}\text { Role conflicts are used actively } \\
\text { to advance one's own identity } \\
\text { into new areas (innovative } \\
\text { spirit) }\end{array}$ & Personality \\
\hline $\begin{array}{l}\text { Adoption of values from other } \\
\text { (external) identities }\end{array}$ & Shaping of one's own values & Values \\
\hline $\begin{array}{l}\text { Strong focus on the } \\
\text { environment }\end{array}$ & Development of a clear vision & Mission and vision \\
\hline Low level of self-confidence & High level of self-confidence & Competences \\
\hline $\begin{array}{l}\text { Lack of consciousness of one's } \\
\text { own achievements (capability) }\end{array}$ & $\begin{array}{l}\text { Achievement and } \\
\text { accomplishments of the past } \\
\text { provide motivation for new } \\
\text { projects. }\end{array}$ & Origin \\
\hline
\end{tabular}

Source: Burmann et al., 2017: 43 - Table 2.4.

Besides the origin, brand identity is primarily based upon the competences of the brand creator company. The competences associated with brand identity refer to those abilities of the company that support the feasibility and authenticity of the brand offer. Successful companies continuously develop and renew their competences in order to remain authentic in the eyes of their target groups and to be able to adjust to the expectations (Burmann et al., 2017: 49).

"The vision determines the brand's long-term development trend" (Burmann et al., 2017: 48). The mission of the brand identity summarizes the assumed role of the brand for the target groups (Burmann et al., 2017: 52). It is an important incentive and motivation both for the internal staff and the external target groups, stating the reason for the existence of the brand, the general convictions supporting its establishment, and the strategic priorities, all of which separate the brand from its competitors (Burmann et al., 2017: 52).

The brand values involved in the construction of brand identity reflect the fundamental beliefs of the brand managers and employees behind the brand, which influences its attitudes and behaviour towards external and internal target groups. The values are the emotional components of the brand, i.e. the principles deemed by the brand to be worth following.

The personality of the brand identity is connected to the values of the brand identity and belongs likewise to the emotional nature of the brand. It denotes the personality traits that internal and external target groups are supposed to associate with the brand (Burmann et al., 2017: 53). The personality of the brand identity is represented by the company employees through their attitudes, way of 
thinking, and behaviour (Burmann et al., 2017: 53). The personality of the brand identity is expressed in the verbal and non-verbal communication style of the brand (Schade, 2012 via Burmann et al., 2017: 53). The brand identity personality contributes to the development of the brand's relations since the customers may build a personal relationship with the brand as a person. Brand identity is incomplete without personality traits, which represent the most important differentiating factor between brands in a fiercely competitive market (Burmann et al., 2017: 53).

The origin of the brand forms the basis of the brand identity. Brand origin is closely connected with the history of the brand, without being identical to the latter. The former is related to the special circumstances and individual facets of the brand's development, in which the brand is rooted. There are three important characteristics of brand origins: geographic origin, the company origin, and the industry origin (Burmann et al., 2017: 45).

For global brands, the brand's country of origin is difficult to determine. Hence, it may happen that the cultural character has greater importance for the brand identity than the country of origin. Nevertheless, the brand's success on the global market is significantly influenced by the way in which people think about the brand's country of origin (Bauer-Kolos, 2016).

The company origin encompasses the attribution of brand to a company. The launching conditions of the company, the company's founders, and outstanding management leaders can significantly shape the brand identity (Burmann et al., 2017: 47). The special characteristics, core values, and competences of the brand are related to the source situation in which the brand was elaborated.

The authors emphasize the importance of the consistency between the elements of brand identity, whose lack damages the brand's unity. The unique brand identity ensures the brand's distinctiveness from its competitors and thus manages to capture and maintain the attention of the internal and external target groups while also creating commitment to the brand.

\section{Specific Features of the Services Brand}

The functioning of companies that are active in service markets is increasingly determined by a service-dominant logic (SDL) (Vargo et al., 2010; Veress, 2009: 29). The central tenet of SDL is that reciprocal service, defined as the application of competencies for the benefit of another party, is the fundamental basis of economic exchange. According to this mind-set, service companies are customeroriented and relational, and the main appreciation comes from customer-based problem-solving ability and relationships.

There are five participating elements in the service delivery process: 
a) the back office, i.e. the background units of the service company (background staff and logistic system);

b) the front office, i.e. the contact units of the service company (the front-line contact staff and contextual factors);

c) the service commodity, of which there can be simultaneously more than one;

d) the customers, who require the service and actively participate in the exchange;

e) other customers, who are simultaneously present at the scene of the exchange (Veress, 2009: 43).

The brand creator company takes account of all elements involved in the service process in the development of the service brand. The service brand conveys a promise both to the customers and to the staff of the service company. Its promise is related to the service commodity, which is intangible for the customer. Due to this intangibility of the service commodity, the customers make their decision primarily on the basis of emotional factors when accessing the service, relying on the opinions and evaluation of other customers.

The customers consider two important dimensions when evaluating the service brand, i.e. the technical and functional quality of the service. The technical quality of the service is associated with the "what" of the service encounter (MorrisonCrane, 2007: 414). The technical quality of the service is a necessary but not a sufficient condition for the customer to be satisfied. The service company may substantiate the technical quality of the service with different certificates, qualifications, and awards presented to the customers. The functional quality is related to the attitude and behaviour of the service company, i.e. the "how" of the service encounter, which increase the satisfaction of the customers and ensure customer retention and loyalty (Morrison, Crane, 2007: 414).

For service brands, the constant maintenance of the brand experience's quality can create difficulties since the service is, in fact, an interaction or relationship between the customers and the staff of the company. The individual, social, cultural, and professional characteristics of the company employees are widely different, and people's daily condition is also changing, while the quality of the service depends on employee wellness. In the case of services, brand perception results in its totality from the encounter and the relationship between the customer and the staff that represents the brand (Riley-Chernatony, 2000: 146).

If the provision of services is for another company (B2B), the provider will emphasize the professional quality of its service in order to ensure success. However, the assessment of company success has revealed that the technical service quality in itself does not ensure the satisfaction of the customer, but adequate customer relations are also needed. The difference between service brand experiences lies in the emotional relationship developed with the customer (Morrison-Crane, 2007: 416). 
For the service brand to be successful, the provider needs to pay attention to the maintenance of the emotional relationship before, during, and after the purchase. In the pre-purchase stage, the positive emotional relationship plays an important role in obtaining the favourable customer decision. During the purchase stage, the maintenance of the positive emotional relationship may be achieved through the involvement of the customer (e.g. the customer may track the progress of the service). In the post-purchase stage, the maintenance of the emotional connection is directed at extending positive emotional attachments with the service brand and the retention of the customer's loyalty (Morrison-Crane, 2007: 418; RileyChernatony, 2000: 137).

The academic literature increasingly stresses the relationship orientation of the service brands (Riley-Chernatony, 2000: 139), while the prerequisite for the success of the brand consists in the provision of a quality service (Berry, 2000: 132). The customer builds on their prior knowledge and emotional impression of the service company when choosing the service brand (Morrison-Crane, 2007: 414). In the case of complex and high-value services, the customer expects valueadding relationships to enrich their service experience (Coleman-ChernatonyChristodoulides, 2011: 1065). At the same time, the creation of the favourable brand experience is also largely influenced by the physical environment of the service company, including, among other things, the furnishing of the premises, office equipment, and other selected sensory effects (Morrison-Crane, 2007: 416). The service brand may be conceived of as the sum of functional and symbolic benefits conveyed to the customer through the quality of the service and of the relationship with the service company (Riley-Chernatony, 2000: 147). The satisfaction of the customer is strongly influenced by the coherence between the attitude and behaviour of the service company staff on the one hand and the service brand promise on the other hand (Chernatony-Harris, 2000: 268).

According to Burry (2000: 130), service companies may develop strong service brands through emphasizing their uniqueness, consequently providing high-quality services and creating a positive emotional relationship with the recipients. The creation of a strong service brand requires constant effort from the company so that it can keep its distinct and unique brand identity up-todate while also constantly searching for new ways of reaching customers and satisfying their demands.

McDonald, Chernatony, and Harris (2001: 346) emphasize the importance of internal brand management through which the brand developers present the mission, values, and competences of the service brand to the staff, thus furthering the development of their brand awareness and brand experience. The company has to support and motivate its employees to behave according to the brand promise, even making the establishment of their contribution conditional upon brand implementation. 
The success of the service brand is significantly influenced by staff attitude and behaviour since the quality of the relationships established with the clients plays a key role in the realization of the brand experience stated by the brand promise for the customers (Buil-Catalan-Martinez, 2016: 4; Burry, 2000: 135). According to Kenesei (2016), the customer's attachment is not so much to the service company but to the employee with whom they collaborate. The shortest path to establish trust relationships between the customer and the service brand consists in the convincing behaviour of the staff that identifies with the brand (Morrison-Crane, 2007: 419).

Buil, Catalan, and Martinez (2016: 10) have found that the differentiating service brand identity also encourages the commitment of the staff to the company and its services, subsequently increasing job satisfaction and providing brand performance. The more the employees internalize the concept and values of the service, the more consistently and effectively they are able to perform it (Burry, 2000: 135).

In the case of $\mathrm{B} 2 \mathrm{~B}$ relationships, the service brand is a representation of the services provided by the company, including the functional and symbolic benefits offered by the brand developers to the customers. The creators of the service brand communicate their ideas to the customers through the name and symbols of the brand, and the customers perceive the brand on the basis of the service quality (functional benefit) and the quality of the emotional relationship with the company (symbolic benefit).

\section{Service Brand Identity Characteristics of Software and IT Companies in Cluj-Napoca - Case Studies Based on the Socio-Scientific Model of Brand Identity}

In the following, I will present a comparison between the service brand identity characteristics of the Cluj-Napoca-based software and IT companies, with special emphasis on the parities and differences of brand identity elements. The choice of the cases studied here was based on the intent to compare the Romanian delivery centre of an international company and a Romanian-founded large company as well as a Romanian-founded large company and a Romanian-founded small company. Accordingly, the three Cluj-Napoca-based companies analysed here are: Endava as the Romanian delivery centre of an international company, Arobs Transilvania as the Romanian-founded large company, and Sinectic Group as the Romanian-founded small company.

The table below presents the service brand identity characteristics of the three investigated companies, following the structure of the socio-scientific brand 
identity model of Burmann et al. (2017). The data presented below reflect the results of the content analysis of the information published on the companies' websites.

Table 2. Characteristics of service brand identity of Endava, Arobs Transilvania, and Sinectic Group

\begin{tabular}{|c|c|c|c|c|}
\hline $\begin{array}{l}\text { Elements of } \\
\text { service brand } \\
\text { identity }\end{array}$ & $\begin{array}{c}\text { Points of } \\
\text { difference - } \\
\text { POD/Points of } \\
\text { parity - POP }\end{array}$ & Endava & Arobs Transilvania & Sinectic Group \\
\hline \multirow[t]{2}{*}{ Origin } & $\begin{array}{l}\text { Points of } \\
\text { difference - } \\
\text { POD }\end{array}$ & $\begin{array}{l}\text { Country origin: UK } \\
\text { Digital large } \\
\text { company } \\
\text { Headquarters in } \\
\text { Cluj-Napoca with } \\
\text { other } 3 \text { Romanian } \\
\text { offices } \\
\text { Global company } \\
\text { with offices in } \\
\text { Western Europe, } \\
\text { Central Europe, } \\
\text { North America, } \\
\text { Latin America }\end{array}$ & $\begin{array}{l}\text { Romanian-founded } \\
\text { large company } \\
\text { Headquarters in } \\
\text { Cluj-Napoca with } \\
\text { other } 6 \text { Romanian } \\
\text { offices } \\
\text { Global company } \\
\text { with } 6 \text { offices in } \\
\text { Europe and Asia: } \\
\text { Germany, Hungary, } \\
\text { Indonesia, the } \\
\text { Netherlands, } \\
\text { Belgium, and } \\
\text { Moldova }\end{array}$ & $\begin{array}{l}\text { Romanian-founded } \\
\text { small company } \\
\text { Office in Cluj- } \\
\text { Napoca }\end{array}$ \\
\hline & $\begin{array}{l}\text { Points of parity } \\
\text { - POP }\end{array}$ & $\begin{array}{l}\text { Developed business } \\
\text { stage with over } 20 \\
\text { years of presence } \\
\text { on the Romanian } \\
\text { market }\end{array}$ & $\begin{array}{l}\text { Developed business } \\
\text { stage with over } 20 \\
\text { years of presence } \\
\text { on the Romanian } \\
\text { market }\end{array}$ & $\begin{array}{l}\text { Developed business } \\
\text { stage with over } 10 \\
\text { years of presence } \\
\text { on the Romanian } \\
\text { market }\end{array}$ \\
\hline \multirow[b]{2}{*}{ Mission } & $\begin{array}{l}\text { Points of } \\
\text { difference - } \\
\text { POD } \\
\end{array}$ & $\begin{array}{l}\text { Digital } \\
\text { transformation }\end{array}$ & -- & -- \\
\hline & $\begin{array}{l}\text { Points of parity } \\
\text { - POP }\end{array}$ & $\begin{array}{l}\text { Customer } \\
\text { orientation } \\
\text { High-quality } \\
\text { services } \\
\text { Relationship } \\
\text { orientation } \\
\text { Global services } \\
\end{array}$ & $\begin{array}{l}\text { High-quality } \\
\text { services } \\
\text { Customer } \\
\text { orientation } \\
\text { Relationship } \\
\text { orientation } \\
\text { Global services } \\
\end{array}$ & $\begin{array}{l}\text { High-quality } \\
\text { services }\end{array}$ \\
\hline \multirow[b]{2}{*}{ Values } & $\begin{array}{l}\text { Points of } \\
\text { difference - } \\
\text { POD }\end{array}$ & Agility & $\begin{array}{l}\text { Innovation } \\
\text { Customer } \\
\text { orientation }\end{array}$ & -- \\
\hline & $\begin{array}{l}\text { Points of parity } \\
\text { - POP }\end{array}$ & $\begin{array}{l}\text { Competitiveness } \\
\text { Success } \\
\text { Commitment and } \\
\text { reliability }\end{array}$ & $\begin{array}{l}\text { Success } \\
\text { Commitment and } \\
\text { reliability } \\
\text { Competitiveness }\end{array}$ & $\begin{array}{l}\text { Customer } \\
\text { orientation }\end{array}$ \\
\hline
\end{tabular}




\begin{tabular}{|c|c|c|c|c|}
\hline $\begin{array}{l}\text { Elements of } \\
\text { service brand } \\
\text { identity }\end{array}$ & $\begin{array}{c}\text { Points of } \\
\text { difference - } \\
\text { POD/Points of } \\
\text { parity - POP }\end{array}$ & Endava & Arobs Transilvania & Sinectic Group \\
\hline \multirow[b]{2}{*}{ Personality } & $\begin{array}{l}\text { Points of } \\
\text { difference - } \\
\text { POD }\end{array}$ & Compassionate & Agile & -- \\
\hline & $\begin{array}{l}\text { Points of parity } \\
\text { - POP }\end{array}$ & $\begin{array}{l}\text { Disciplined } \\
\text { Passionate } \\
\text { Creative } \\
\text { Collaborative }\end{array}$ & $\begin{array}{l}\text { Creative } \\
\text { Disciplined } \\
\text { Passionate } \\
\text { Collaborative }\end{array}$ & Disciplined \\
\hline \multirow[b]{2}{*}{ Competences } & $\begin{array}{l}\text { Points of } \\
\text { difference - } \\
\text { POD }\end{array}$ & -- & -- & -- \\
\hline & $\begin{array}{l}\text { Points of parity } \\
\text { - POP }\end{array}$ & $\begin{array}{l}\text { Professional } \\
\text { awards, } \\
\text { certifications, } \\
\text { accolades, } \\
\text { distinctions } \\
\text { Professional } \\
\text { management } \\
\text { Successful projects }\end{array}$ & $\begin{array}{l}\text { Successful projects } \\
\text { Professional } \\
\text { awards, } \\
\text { certifications, } \\
\text { accolades, } \\
\text { distinctions } \\
\text { Professional } \\
\text { management }\end{array}$ & -- \\
\hline \multirow[b]{2}{*}{ Offers } & $\begin{array}{l}\text { Points of } \\
\text { difference - } \\
\text { POD }\end{array}$ & $\begin{array}{l}\text { Digital } \\
\text { transformation }\end{array}$ & $\begin{array}{l}\text { Premium prices } \\
\text { Unique company } \\
\text { culture }\end{array}$ & $\begin{array}{l}\text { Premium prices } \\
\text { Digital } \\
\text { transformation }\end{array}$ \\
\hline & $\begin{array}{l}\text { Points of parity } \\
\text { - POP }\end{array}$ & $\begin{array}{l}\text { Customer } \\
\text { orientation } \\
\text { High-quality } \\
\text { services } \\
\text { Social } \\
\text { responsibility }\end{array}$ & $\begin{array}{l}\text { High-quality } \\
\text { services } \\
\text { Customer } \\
\text { orientation } \\
\text { Social } \\
\text { responsibility }\end{array}$ & $\begin{array}{l}\text { Customer } \\
\text { orientation } \\
\text { High-quality } \\
\text { services }\end{array}$ \\
\hline
\end{tabular}

Source: from the content analysis of data collected in 2018 from websites: endava.com, arobs. com, synectics.ro

\subsection{Endava}

Endava is a global company of British origins with three Romanian offices (Bucharest, Cluj-Napoca, Iaşi). Its Cluj-Napoca office was created in 1997. From the point of view of its operational history, it can be regarded as a developed company. In 2016, the number of staff employed at the Cluj-Napoca office was 1812. Hence, on the basis of the number of employees, it can be regarded as a large company. The Romanian establishments of Endava rely on the outsourcing business strategy, fulfilling market orders from abroad while relying on Romanian workforce. Their most important customers come from economic sectors such as finances, insurance, telecommunication, media, technology, and retail trade. The company helps with the digital transformation of the customers from these economic sectors in the domain of production, sales, management, and communication. 
The analysis of the website of Endava clearly reveals messages aimed at clients, conveying a reliable service brand identity. The existence of the service brand identity is confirmed by the fact that the website content allows for the identification of the elements that are included in the construction of brand identity according to the integrated brand identity model developed by Burmann et al. Endava's slogan is "We deliver digital transformation", i.e. the essence of the company's service brand consists in furthering the digital transformation of the customers.

The origin of Endava's service brand identity is structured around three keywords: "global", "digital", and "large company". Its mission statement emphasizes customer orientation and high professional standards, enriched by the relationship orientation and the service of digitization, realized within the partnerships. The company assumes its global character even in its mission statement. Its main values include competitiveness and successfulness, which can be counted among the basic principles of any service company's strategy. One of the important values of Endava consists in its commitment to customers and employees, denoting the importance of relationships. Still another differentiating value is agility, meaning "the capacity to exploit market opportunities quickly and in surprising ways" through innovative IT solutions, covering the area of customer service, cooperation, and operative functioning (Nemeslaki, 2012). The brand identity personality of Endava, which can be characterized through traits such as discipline, creativity, passion, cooperation, and compassion, is in accordance with these values. The service offers of Endava fit harmoniously into this semantic field, emphasizing customer orientation, contribution to the digital transformation of companies, and the provision of a high level of professional services. The feasibility of the offers is substantiated by the presentation of numerous professional awards achieved by the company for the excellence of its functioning and the professional quality of its services. The successful functioning of the company and its competitiveness are ensured by the highly trained and professional management. The mission statement and the values, the competence elements that are presented, and the personality elements are consistent with each other. The differentiating service brand identity offer of Endava refers to its contribution to the digital transformation of the customers, in consonance with which the guarantee for the growth and development of market participants lies in their capacity to catch up with the changes brought about by the so-called digital revolution. Overall, Endava has a clear brand identity, characterized by service centredness, customer orientation, market leader ambitions, and a relational approach. 


\subsection{Arobs Transilvania}

Arobs Transilvania is a large Romanian-founded software and IT company created in 1998. According to its operation history, the company is in its developed phase. It is a large company, which had 457 employees in 2016. Its business strategy is characterized by the reliance on in-house workforce. However, from the point of view of its market expansion, it considers itself a global company. Its services are provided on fields such as transport and logistics, the automotive industry, financial services, telecommunication, healthcare, travel, and media.

The landing page of the company website contains its mission statement as a service provider, which reflects a service-dominant view that is different from that of Endava. Arobs Transilvania emphasizes its European origins and international culture. At the same time, it also emphasizes its status as a global software and IT service provider, offering finished products and on-demand software and IT services developed on the basis of the most recent digital technologies.

The company website contains all the structural elements of the service brand identity. The web subpage of the company contains origin elements of the service brand identity, revealing that it is a Romanian-founded large company dominated by Europeanism in its corporate culture while being geographically global. The emphasis on Europeanism is important also because foreign service customers view Romania as an attractive outsourcing country when compared to China or India, due precisely to its cultural identity. The company's landing page does not contain any slogan that would synthetize the service identity mission.

The mission of Arobs Transilvania's service brand identity is strong and clear. It is characterized, similarly to the case of Endava, by high-level professional services, customer orientation, and the establishment of professional partnerships. Arobs Transilvania assumes in its mission the task of continuous technological and knowledge renewal. However, the contribution to the customers' digital transformation receives less emphasis. The company highlights its global character already on the landing page of its website, but, unlike in the case of Endava, this does not refer to global geographical presence but to a global service offer. The company mission and the offers fit together as the company proposes the following offers, which naturally follow from its assumed role: high-level professional services, customer orientation, and social responsibility. Additionally, the offers include the creation of a unique corporate culture and premium prices, which provide differentiation. Among the values of the service brand, one may identify values similar to those of Endava. Their similar service values include successfulness, competitiveness, and commitment. The differentiating value of Arobs Transilvania consists in innovation. This company also lists numerous competences in order to substantiate its offers, including its successful projects, competitive management, customers' evaluation of the 
company, and various awards and recognitions. The company's personality is characterized by traits such as discipline, creativity, passion, cooperativeness, and agility. These traits outline a brand personality similar to that of Endava. Arobs Transilvania is emphatically agile, which denotes the service centredness by vigilant monitoring of customer demands. In sum, a clearly defined service brand identity is identifiable also in the case of Arobs Transilvania. This company's identity is characterized by attributes such as professional competence, commercial success, competitiveness, and responsibility for social development.

\subsection{Sinectic Group}

Sinectic Group is a Romanian-founded small software and IT company established in 2006. The company has 14 employees. Its business strategy consists in the reliance on in-house workforce. The company considers the international market as its own. It provides software and IT services for foreign and domestic customers. With its operation history of more than a decade, this company is also in the mature phase of its development, but, due its small number of employees, it counts nevertheless as a small company. The company is based in Cluj-Napoca, but, in addition to the domestic customers, it fulfils orders from Belgium, England, and France as well.

This company does not identify on its website the economic sectors of its customers, but it outlines in detail the technological knowledge of the company. The company website does not contain any slogan, and its mission statement is restricted to offering high-level professional services. The offer component of the service brand identity is more complex than the mission statement since it contains elements such as customer orientation, premium prices, and the contribution to the digital transformation of its customers. The main value of the company's service brand identity is its customer orientation, while its onedimensional personality may be characterized by discipline. The company does not substantiate its offer through successful projects or awards and recognitions but only emphasizes that it collaborates with foreign customers as well. All in all, the service brand identity of the company Sinectic Group is on the basic level, and the differentiating characteristics pointing beyond technological endowments cannot be identified.

\subsection{The Comparison between the Service Brand Identities of the Analysed Cluj-Napoca-Based Software and IT Companies}

The figure below presents the constitutive differences between the brand identities of Endava, Arobs Transilvania, and Sinectic Group. The brand identities of the two large companies have many points of parity, but there are differentiating 
points as well. The incompleteness of the service brand identity of Sinectic Group is striking in comparison.

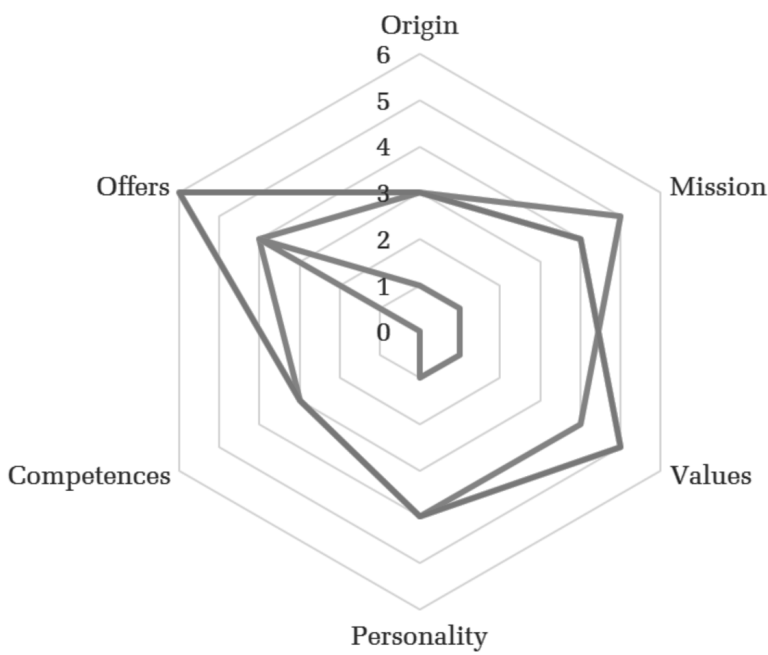

Endava

Arobs Transilvania

Sinectic Group

Figure 2. Comparison of the constitutive elements of service brand identities of Endava, Arobs Transilvania, and Sinectic Group

The mission statements of the two large companies - Endava and Arobs Transilvania - contain common points, characteristic of the general profile of service brands in the Romanian software and IT sector (Tókés, 2019). The common points of the mission statements include the provision of services of high quality, increased attention to the customer, and orientation towards the global markets. Endava differentiates itself in its mission statement, in which the contribution to the implementation of the digital transformation appears as a new mission element. The mission statement of Sinectic Group can be considered deficient since it only emphasizes the provision of high-quality services among the mission elements constituting its general profile.

As far as the constitution of the service brand identity is concerned, the common values of the two large companies include successfulness, competitiveness, and commitment as a service provider. The differentiating value of Endava consists in its agility, i.e. its intelligent responsiveness to market challenges and to the expectations of the customers, denoting service-centredness. The differentiating value of Arobs Transilvania is innovation, i.e. the ongoing attention to technological innovations and their application in the process of searching for customized solutions for the benefit of the customers, which puts the emphasis rather on technical excellence. Finally, the value element of the brand identity in the case of Sinectic Group can be considered deficient as it does not present any general or differentiating values on its company website. 
The common personality traits of the service brand identities of Endava and Arobs Transilvania include discipline, passion, creativity, and collaboration. The differentiating personality trait of Endava consists in its compassion, used in its relation to its environment. In the case of Arobs Transilvania, the differentiating personality trait is its agility used in its relationships with its customers. As for the company Sinectic Group, the personality of its brand identity may be regarded as incomplete since it only emphasizes the importance of discipline.

The common competence elements of the service brand identity of the companies Endava and Arobs Transilvania are the professional awards and recognitions along with the presentation of their successful projects and exceptional leaders. However, neither of the two companies presents any differentiating competence elements. In the case of the enterprise Sinectic Group, this component of brand identity is completely absent.

In the case of the companies Endava and Arobs Transilvania, the service offers unanimously highlight their service-centredness and relationship orientation since both offer high-quality software and IT services, increased and customized attention to their clients, and corporate social responsibility. The differentiating offer of Endava relates to the digital alignment of their customers to the implementation of the digital transformation. The differentiating offer of Arobs Transilvania is related to the premium prices and to the unique corporate culture. The differentiating offers also highlight the different corporate philosophy of the two large companies examined here: the emphasis on the strong professional identity of Endava as a digital company, thinking beyond technology itself and having sophisticated insights about the customers who will adopt and use the technology (Mohr-Sengupta-Slater, 2010: 4); the emphasis on the engineering developments, customer- and relationship-centredness of Arobs Transilvania. It is perhaps the brand offers along which the service brand identity of the company Sinectic Group comes closest to that of the two large companies. The differentiating offer of the small Romanian company is based on its contribution to the digital transformation and its premium prices, which also denote customer-centredness.

The analysis of the service brand identity of the three companies in ClujNapoca and their graphical representation clearly indicate the complexity of Endava's and Arobs Transilvania's brand identity as well as the deficiencies of the brand identity in the case of Sinectic Group. 


\section{Interpretation of the Software and IT Companies' Service Brand Identity on the Basis of the Cluj-Napoca Company Case Studies}

The nature of the service brand identity differs from the identity of the product brands since the market operators who receive the service primarily rely on rational criteria in their decisions, which increases the importance of functional advantages. However, this does not mean that the symbolic advantages offered by the service brand, e.g. the values or personality, do not play any role in the customers' decisions. This is especially true on the market of software and IT services, where the degree of uncertainty is high, change is fast-paced, and the final form of the products and services is constantly evolving (Bauer, 2016). The presented case studies also support the importance of symbolic advantages since a similar value system and personality have emerged in the construction of brand identity for both Endava and Arobs Transilvania. At the same time, it has also become clear that all three of the investigated companies emphasize their servicecentredness and relationship orientation both in their mission statement and offer.

The market of software and IT services is B2B market. These markets exceed the size of consumer markets and also differ from them in their outlook since production and technical culture is dominant here along with customer orientation. The services are delivered to other companies, and the service provider company's positioning is also primarily based on technical properties. The number of customers is relatively low on the B2B market, while the volume and strategic importance of business exchanges are significant. In such circumstances, objective evaluation and the continuous exploitation of commercial advantages are much more important than emotions. At the same time, the paramount importance of business transactions tends to valorize the customized offers for the business parties along with the importance of emotional advantages and relationships in choosing the service brand (Bauer, 2016). This feature of the market has left its mark on the service brand identities of all three software and IT companies in Cluj-Napoca. All three of them have based their service brand primarily on the professional knowledge and technological competence combined in the company. Even in the case of the company called Sinectic Group, which may be characterized by a less complex service brand identity, the professional and technical characteristics have successfully been emphasized.

Following the spread of digital technology, B2B markets - including service markets - underwent enormous changes since digital transformation radically modified the production, sales, organizational and communication processes. Digital technology has made it possible for global markets to emerge, and such markets are especially characteristic of the software and IT service areas. 
Positioning themselves on the global market formed part of their mission for both Cluj-Napoca software and IT companies possessing strong brand identities. The opening towards foreign markets is articulated even in the case of the company called Sinectic Group, possessing a basic brand identity, which is creditable for a company with 14 employees.

The world of high technology is filled with both promises and perils (MohrSengupta-Slater, 2010: 4). The software and IT services market is characterized by a high level of market and technological uncertainty, requiring special strategic and brand management solutions (Bauer, 2016). Software and IT companies sometimes face difficulties in exploring the needs, concerns, and problems of their customers - who are active in non-technological sectors - regarding the application of technological solutions (Mohr-Sengupta-Slater, 2010: 5). As for the customers, they may be afraid of radically innovative solutions because they do not know whether these will truly satisfy their business requirements. Additionally, software development also requires time, while customers' demands are quickly changing (Mohr-Sengupta-Slater, 2010: 13). Customers raise doubts about applicability, i.e. regarding whether the innovative solutions will fulfil the hopes invested in them. Technological uncertainty is also increased by the fact that the provider is not necessarily capable of producing great volumes fast (Bauer, 2016). Finally, the extent to which new developments will be compatible with former technological solutions is also doubtful, as is the provider's service capacity in the case of operational blockages (Mohr-Sengupta-Slater, 2010: 15).

The uncertainty factors bring added value to the efforts directed at creating and maintaining trust, including the substantiation of the brand identity's professional offers with competences and the implementation of relational measures such as the emphasis on long-term professional cooperation and partnerships based on mutual advantages as well as the complete transparency of the entire service process. Along the service process, trust and reliability become important factors, adding to the value of service brand management. Trust building and the substantiation of reliability represented an essential criterion for the ClujNapoca-based software and IT companies possessing complex service brand identities. An indispensable element of a complex service brand identity consists in the underpinning of the feasibility of the offers with previous successful projects, professional awards, recognitions, and not least with having a reliable professional team. The competence element of the service brand identity of both Endava and Arobs Transilvania contains all three indicators, while in the case of the less complex brand identity of the company called Sinectic Group the trustbuilding elements were completely missing.

It is worth emphasizing that the brand management activity is primarily characteristic of the large companies and is less prevalent in the everyday functioning of small and medium-sized enterprises (Spence-Essoussi, 2008: 1038; 
Muhonen-Hirvonen-Laukkanen, 2017: 2). This was also the case with the three investigated software and IT companies in Cluj-Napoca. The studies support that if small and medium-sized enterprises pay attention to their brand management activity and build their brand identity, then this positively influences their brand performance (Hirvonen-Laukkanen, 2014: 41). That is why the importance of brand identity building for small and medium-sized enterprises is worth to be especially emphasized as these companies tend to develop the technological value of their services while paying less attention to the segmentation and positioning expectations of the market. This statement applies especially to Sinectic Group. The website content of Sinectic Group demonstrated the less conscious attitude of small companies towards the area of brand management.

\section{Conclusions}

The development of strong service brand confers market advantage under conditions of strong economic competition, which is a priority area of corporate identity management (Nádasi, 2016: 120). In the case of service companies, the goal of brand management is to create a strong service brand, the first steps for which include the elaboration of the service brand identity. The service brand identity contains all the essential brand associations which ensure the alignment to the service market according to the specific service field (points-of-parity, POP). At the same time, brand identity also stresses the differences (points-of-difference, POD) that strengthen the successful positioning of the brand on the service market.

One of the goals of this study was to present the socio-scientific-based brand identity model of Burmann et al. (2017). The survey of the marketing-oriented brand identity models (Aaker, 2002; Aaker-Joachimsthaler, 2009, 2014; Kapferer, 2008) highlighted the fact that brand identity is made up of certain key elements, including the mission statement, values, personality, and the offer. Based on the results of personal identity research, Burmann et al. (2017) complement the aforementioned elements of the constitution of brand identities with two further important components, i.e. origin and competences, since brand identity is able to create long-term benefits if it is endowed with the ability of self-reflection and renewal. The offer of brand identity becomes authentic and attractive only if it is sound and sustainable in the long term.

The other goal of this study consisted in applying the socio-scientific-based brand identity model of Burmann et al. (2017) through the analysis of the service brand identities of three Cluj-Napoca-based software and IT companies. The empirical testing of the aforementioned theoretical model highlights the possibility of applying scientific knowledge, which can be regarded as an innovative result in the area of brand management. 
The analysis of the brand identities of the three Cluj-Napoca-based software and IT companies presented in this study, using the brand identity model of Burmann et al. (2017), can be regarded as significant in several respects. The analysis demonstrated the empirical usability of the model, which is suitable both for assessing the identity of the existing service brands and for planning future service brands. The results of the analysis have shed light on the points of parity of the service brand identities of software and IT companies and highlighted the brand identity elements that enable differentiation (points-of-difference). The common points of the service brand identity of the Cluj-Napoca-based software and IT companies consisted in the emphasis on technical competences as well as customer and relationship orientation. Their differentiation was possible along their values and personality that represent the symbolic benefits of service brand identity. Their symbolic differentiation also resulted in the differentiation of their offers.

The practical application of the socio-scientific-based brand identity model of Burmann et al. (2017) represents an important contribution to the extension of the research results in this field of studies. The survey of the academic literature has led to the recognition that there are mostly theoretical models in existence with regard to brand identity. However, their empirical testing is much less prevalent. The methodological use and testing of the theoretical models also contribute to the enrichment of the practical professional knowledge. At the same time, several knowledge elements that are important for the theoretical profession have emerged as well since the case studies of the Romanian software and IT sector may be relevant for the practice of service brand analyses and planning in the Romanian software and IT sector.

The research presented in this study may be developed in several directions, one of them being the quantitative direction. It would be worthy to increase the number of case studies and to proceed thus to the comparative analysis of several service brand identities in order to highlight the main points-of-parity and points-of-difference characteristic of the service brand identities of the Romanian software and IT sector. The qualitative development of the study would consist in the analysis of the full service brand management process by surveying the brand teams' concepts behind the service brand representations. 


\section{References}

Aaker, D. A. (2002). Building Strong Brands. London-Sydney-New YorkToronto: Pocket Books.

Aaker, D. A.-Joachimsthaler, E. (2009). Brand Leadership. London-Sydney-New York-Toronto: Pocket Books.

Alsem, K. J.-Kosteijk, E. (2008). Identity Based Marketing: A New Balanced Marketing Paradigm. European Journal of Marketing 42(9-10): 907-914.

Balmer, M. T. J.-Gray, R. E. (2003). Corporate Brand: What Are They? What of Them? European Journal of Marketing 37(7-8): 972-997.

Bauer, A. (2016). Márkázás a szervezetközi piacokon [Branding on B2B Market]. In: Bauer, A.-Kolos K. (eds.), Márkamenedzsment [Brand Management]. Budapest: Akadémiai.

Bauer, A.-Kolos K. (2016). Márkamenedzsment [Brand Management]. Budapest: Akadémiai.

Berry, L. L. (2000). Cultivating Service Brand. Journal of the Academy of Marketing Science 28(1): 128-137.

Buil, I.-Catalan, S.-Martinez, E. (2016). The Importance of Corporate Brand Identity in Business Management. An Application to the UK Banking Sector. Business Research Quarterly 19: 3-12.

Burmann, Ch.-Jost-Benz, M.-Riley, N. (2009). Toward an Identity-Based Brand Equity Model. Journal of Business Research 62(3): 390-397.

Burmann, Ch.-Riley, N-M.-Halaszovich, T.-Schade, M. (2017). Identity-Based Brand Management. Fundamentals - Strategy - Implementations - Controlling. Springer.

Chernatony, L. (2010). From Brand Vision to Brand Evaluation. The Strategic Process of Growing and Strengthening Brands Amsterdam-Boston-London: Butterworth-Heinemann.

(2014). From Brand Vision to Brand Evaluation. The Strategic Process of Growing and Strengthening Brands. New York: Routledge.

Chernatony, L.-Harris, F. (2000). Developing Corporate Brand through Considering Internal and External Stakeholders. Corporate Reputation Review 3(3): 268-274.

Chernev, A. (2017). Strategic Brand Management. Evanston, Illinois: Northwestern University.

Coleman, D. A.-de Chernatony, L.-Christodoulides, G. (2011). B2B Service Brand Identity: Scale Development and Validation. Industrial Marketing Management 40: 1063-1071.

Esch, F. R. (2008). Brand Identity: The Guiding Star for Successful Brands. In: Schmitt, B. H.-Rogers, D. L. (eds.), Handbook on Brand and Experience Management. Cheltenham: PEFC, 58-75. 
Kapferer, J. N. (2004, 2008). The New Strategic Brand Management. Creating and Sustaining Brand Equity Long Term. London: Kogan Page.

McDonald, M. H. B.-de Chernatony, L.-Harris, F. (2001). Corporate Marketing and Service Brands. Moving beyond the Fast-Moving Consumer Goods Model. European Journal of Marketing 35(3/4): 335-352.

Mohr, J.-Sengupta, S.-Slater, S. (2010). Marketing of High-Technology Products and Innovations. New York: Prentice Hall.

Morrison, S.-Crane, F. (2007). Building Service Brand by Creating and Managing an Emotional Brand Experience. Brand Management 14(5): 410-421.

Muhonen, T.-Hirvonen, S.-Laukkanen, T. (2017). SME Brand Identity: Its Components and Performance Effects. Journal of Product \& Brand Management 26(1): 1-44.

Nádasi, K. (2016). Márkakommunikáció [Brand Communication]. In: Horváth, D.-Bauer, A. (eds.), Marketingkommunikáció. Stratégia, új média, fogyasztói részvétel [Brand communication. Strategy, New Media, and Consumer Involvment]. Budapest: Akadémiai.

Riley, F. D.-Chernatony, L. (2000). The Service Brand as Relationship Builder. British Journal of Management 11: 137-150.

Schultz, M.-Hatch, M. J.-Adams, N. (2012). Managing Corporate Reputation through Corporate Branding. In: Pollock, T. G.-Barnett, M. L. (eds.), The Oxford Handbook of Corporate Reputation. Oxford: OUP, 420-446.

Spence, M.-Essoussi, H. (2010). SME Brand Building and Management: An Exploratory Study. European Journal of Marketing 44(7): 1037-1054.

Tókés, Gy. (2019). Online Branding - Online Branding Strategies in the IT Sector. The Service and Employer Brand Identities of the Companies Operating in the Field of Software and IT Services in Cluj-Napoca Based on the Corporate Data Published on Their Websites (PhD thesis). Cluj-Napoca: Babeş-Bolyai University.

Urde, M. (2013). The Corporate Brand Identity Matrix. Journal of Brand Management 20(9): 742-761.

Urde, M.-Baumgarth, C.-Merrillees, B. (2011). Brand Orientation and Market Orientation. From Alternatives to Synergy. Journal of Business Research 66(1): 13-20.

Veress, Z. (2009). A szolgáltatásmarketing alapkönyve [Handbook of Service Marketing]. Budapest: Akadémiai. 